\title{
Neighbourhood Streets as Public Space. COVID-I 9 Public Life in Kimisange, Rwanda
}

\author{
Josephine Mwongeli Malonza \\ University of Rwanda, Rwanda \\ josemwongeli@yahoo.com
}

\begin{abstract}
Since the World Health Organisation (WHO) declared the Covid-19 a global pandemic in March 2020, countries have had to swiftly adopt lockdowns and social distancing measures in order to prevent worse public health outcomes that are likely to influence the relationship between urban society and space. Whereas the economic impact of the pandemic is obvious, its influence on public life remains uncertain, and yet the pandemic has drastically changed our relationship with our streets, public spaces and public facilities. A longer-term concern lies in understanding the risk that living the new normal could have on our future perception and use of public space. Using activity mapping on a neighbourhood street in Kigali, Rwanda, this paper explores the relationship between public space and quality of life before and during Covid-I 9 lockdown. The research found that neighbourhood streets are increasingly becoming popular for recreational activities, and hence more valuable to users. This positive sensory experience, at a time when the pandemic preys on public life in urban areas, shines new light on the notion of street as public space.
\end{abstract}

Keywords: COVID-19, neighbourhood street, public space, quality of life, Rwanda

To cite this article:

Malonza, J. M. (2020). Neighbourhood Streets as Public Space. COVID-I 9 Public Life in

Kimisange, Rwanda, The Journal of Public Space, 5(3), 39-52, DOI I0.3289I/jps.v5i3.I367

This article has been double blind peer reviewed and accepted for publication in The Journal of Public Space. 


\section{Introduction}

Public space is an integral part of our cultural, social and economic heritage, making it a stage for interaction, socialization and representation of society and culture (Carmona, Heath, Oc, and Tiesdell, 20I0; UN-Habitat, 20I5). Intuitively, public space plays an 'interactive role' in society; it catalyses a relation between the intangible (people's activity) and the tangible (physical space). In the recent decades, the way citizens relate to the public dominion has deeply changed towards more and more bottom-up, pop-up and temporary interventions taking place in the public realms (Caldwell and Guaralda, 2016). The New Urban Agenda (NUA) adapted in 2016 during the third habitat meeting in Quito emphasizes on the need for a shared vision towards a better and more sustainable future, and speaks directly to and brings forth the fundamental values of public space in the way its various principals relate to its flexibility and quality. NUA envisions a process through which public space increasingly embraces multifunctionality, inclusivity, social interaction and participation (Garau et al. 20I5). However, this progress has become prone to global disasters and shockwaves like the one that came with the Covid-19 pandemic, disrupting the public realm in most parts of the globe. In this perspective, the pandemic is said to be drastically changing our relationship with our streets, public spaces and public facilities (UN-Habitat 2020). WHO's declaration of the Covid-19 as a pandemic, and the response by many countries to impose significant restrictions on the size, purpose and location of gatherings in public space and other health measures is likely to have a tremendous influence on the relationship between urban society and space. In order to slow down the transmission of Covid-19, people have been encouraged to stay home unless when seeking essential services, observe physical distancing and wear masks when in public (WHO 2020a). Lockdowns and/or cessation of movements have been enforced in many cities. Physical distancing rules were introduced, and it is said in the better part of 2020, half of the worlds' population stayed at home to help prevent the spread of the pandemic (Sandford, 2020). Clearly, before a cure or vaccine could be found, the physical space has become the mechanism to fight the pandemic. It is against this backdrop that an understanding of how the pandemic is influencing public life and hence use of public space, is sought. Certainly, these rapid measures have a tremendous influence on the relationship between urban society and urban space. It has remained unclear if the impacts of COVID-19 on public space will be as profound as they are in other aspects of our life (Corbera et al. 2020) and this is expected to take several years to ascertain due to the immediacy of the pandemic. This allows us to keep pursuing the existing urban development trajectile, while carrying more optimism to the fundamental changes the pandemic is likely to bring to our future urban practices and values.

Rwanda recorded her first case of Covid-19 on 14 ${ }^{\text {th }}$ March 2020 and rapid contact tracing as well as preventive measures such as social distancing, hand-washing and/or sanitizing stations were placed in bus stops and major shopping centres and markets. On $20^{\text {th }}$ March 2020, a national lockdown was put in place and only movement for essential services was permitted, until $30^{\text {th }}$ April when the lock down measures were readjusted to allowing movement but with strict use of masks in public and a curfew from $2000 \mathrm{~h}$ to $0500 \mathrm{~h}$ was instituted. A second national lockdown was put in place on $18^{\text {th }}$ to $31^{\text {st }}$ May and a later lockdown of Kigali city from $3^{\text {rd }}$ to $22^{\text {nd }}$ February 2021 with a curfew of $1900 \mathrm{~h}$ to $0400 \mathrm{~h}$ in place (GOR, 2020). Similar to other government policies in the country, the public health responses to Covid- 19 have been robust and adhered to 
by citizens.

Despite the interruption by the Covid-19 pandemic, Rwanda remains keen on localizing Sustainable Development and has made commendable efforts in this path (Government of Rwanda 2015; Bhowmick, 2019). As the nation's Vision 2020 (Government of Rwanda 2012) comes to an end, a transitional strategy, referred to as the National Strategy for Transformation (NST I), has been put in place to propel Rwanda to urban prosperity and sustainability (Government of Rwanda, 2019a). Whereas the growth and development of a city ought to be accompanied by the provision of adequate public space that serves as a place for social interaction, to date, there is no series of public spaces for Rwandan cities (Gubic and Oana, 2020). Surprisingly, an historical look confirms that public space was deeply rooted in the Rwandan traditional setting, whereby the everyday life of society revolved around public space (Malonza, 2018). Filling this gap calls for a combination of both the top-down institutional policy frameworks as well as bottom-up 'home grown solutions' through public involvement. The expectation that these efforts could result in positive outcomes remains valid since public space and related processes are ever evolving with time, bringing in new variety, complexity and richness that was rarely experienced in the past (Bravo and Guaralda, 2016).

In August 2015, Kigali celebrated the implementation of a car free zone for exclusive use by pedestrians (Malonza and Rukwaro, 2017), being the first ever formally recognized public space in Kigali's central business district (CBD). This initiative had been inspired by the 2013 Kigali city master plan, that emphasized on a green transport theme, aiming to achieve higher quality of life and climate resilience. With respect to outdoor activities, Kigali city conducts two car-free days each month, aimed at promoting physical activities such as fitness, jogging and outdoor games on urban roads temporary closed for vehicles (Gubic and Baloi 2020), which leads to healthy lifestyles. While gyms and stadia remained closed during the lockdowns, homes and neighbourhood streets became the only hope for recreational activities. With respect to community projects, Rwanda conducts a national monthly communal cleaning event referred to as umuganda, which leads to social interaction between people while at the same time creating something beautiful and meaningful to them. With lock downs, social life benefits keep diminishing and it is feared people may lose the sting of having to meet friends in public space. These conceptualisations and innovative use of urban space in pre-Covid-19 Rwanda, confirm that outdoor space can be seen as a productive landscape for health and social development (Armstrong, 2000).

Although there has been a growing evidence on the adaptation of public space to climate change and natural disasters (Silva and Costa, 20I8), Public space adaptability to pandemics has not been widely studied, until it became of paramount importance in the Covid-I 9 era. Existing studies tend to focus on the overall subject of public space, with the aim to measure proportions and recommend means to increase their quantity and qualities. The influence of these attributes during a pandemic and the transformational impact of the 'lockdown' measures remains unexplored. The purpose of this paper is therefore to identify the extend to which the Covid-19 pandemic influenced use of public space, and a further exploration of how the new ideas and measures can be integrated into practice. The results could serve as evidence for future design and policymaking to facilitate safer and healthier access to public space, during pandemic and beyond. The analysis of user activities before and during lockdown is examined using 
activity mapping. The following sections describe the theoretical underpinnings, research methods and analysis of the relationships between users and activities in a neighbourhood street as public space, and their differences before and during Covid- 19 lockdowns.

\section{Literature review}

\section{I. Humans and urban space}

Humans are social by nature, and our everyday life is constructed around the way we interact with others and with spaces around us. It takes human presence in urban space for social interaction to happen, which is furthermore a key ingredient to health and wellbeing, and a top priority for humanity in times of pandemic and hardships.

According to Kevin Lynch, no factor of city is experienced automatically, unless it is known in relation with its environment and hierarchy of events which cause its occurrence and existence and they are experiences of memories (Lynch, 1960). The notion that cities belong to and are about people engages the understanding that the social dimension of space; people's presence in space and their activities carries more weight than the physical dimension of space itself. In this perspective, urban environments are beyond a collection of buildings separated by streets or parks but an "art of relationship" (Tibbalds, 1992; Cullen, 1975).

According to Gehl (1987), as illustrated in Figure I, the environment-human relationship can be categorized into three; A) Necessary activities are mandatory, leave participants with no choice and hence have to happen regardless of the status of the outdoor environment for instance going to school or shopping. B) Optional activities, which take place if time and place (good setting and weather) allow for instance recreational walks or playing. C) Social activities, which depend on the presence of others in public space to happen for instance participating in group sports or organized social activities (Gehl, 1987; Mehta, 20I4). It is concluded that a good outdoor environment makes a space more usable and desirable.

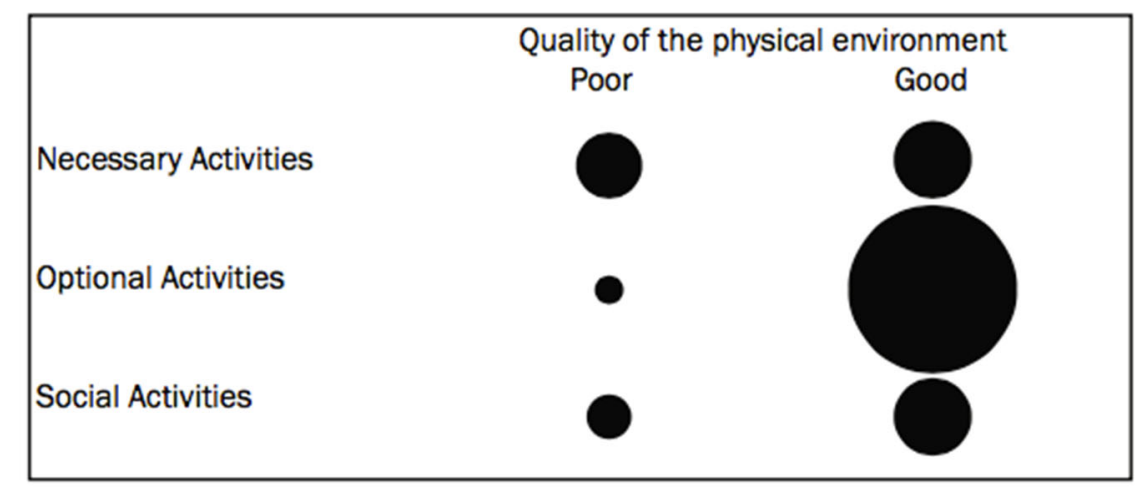

Figure I. The relationship between quality of physical environment and public life. Source: Gehl (1987)

Carmona (2019) has further argued that quality urban public spaces are also safe, comfortable, and relaxing, with safety induced by public surveillance that people provide 
as well as the balance between pedestrians and traffic (Carmona, 2019). This in itself makes public space a multi-functional space, whose flexibility; stability and adaptability is largely determined by users and events.

Interestingly, De Meulder and Heynen (2003), conceptualized the role of public space using three analogies; space as neutral, receptor and reflector of socio-economic processes, space as a possible tool in the launch of certain social processes and space as a scene in which social processes occur. They argue that when space is viewed as neutral, receptor and reflector of socio-economic processes, the focus shifts from it being 'a determinant experienced', to it being the 'influence exerted'. Further, space is seen as a possible 'tool' in the launch of certain social processes, while additionally becoming the 'scene' in which these social processes occur. Their study captures both the actions and interactions between the 'scene and the play', as would be applicable in the spatial organization of most neighborhoods and cities in the world (De Meulder and Heynen, 2003).

\subsection{Public Space and Quality of life}

Quality of life is seen as the outcome of the interaction of human and urban environment (Das, 2008) and is believed to be the driver of a city's prosperity and sustainability, by promoting urban commons and public good for all (UN-Habitat 2015). During pandemics such as the Covid-19 pandemic, the relationship between human and environmental health becomes more paramount. In response to this, the $\mathrm{WHO}$ and UN-Habitat released a Sourcebook (2020), 'Integrating Health in Urban and Territorial Planning', which is designed to guide decision makers from the public health, urban and territorial planning sectors including planners, city managers, health professionals and others towards developing sustainable and healthy cities planned and built with health at the core (UN-HABITAT and WHO, 2020)

Therefore, satisfaction with urban environments remains a key indicator of quality of life as public space remains an integral part of urban environments. Since public space serves as a meeting place that is open and freely available for all, it has every potential to increase the quality of life in terms of social interaction, creating attractive environments, encouraging participation of activities in public space and ensuring the safety of users.

Access to outdoor activities directly impacts on people's ability to live longer and healthier (Thompson, 2008; Van den Berg, et al., 2010). People living near green spaces seem to enjoy higher levels of recreation as they spent more time doing physical activities than others and people with access to green spaces enjoy healthy transport, reduction of stress and better weight management (Björk, et al 2008; Nelson and Hansen 2017). A line of trees on a street can go a long way in improving the perceived safety of the same and encouraging drivers to keep low speeds. (Dumbaugh and Gattis, 2005). It is no wonder that public playgrounds near vegetation are used more frequently and experienced as better than other playgrounds.

\subsection{Links of public space to health and wellbeing}

Research has reported the association between contact with public spaces and health benefits both at the individual and population level (Lee and Maheswaran 20I I; Kondo et al., 2018). The underlying health benefits of public spaces are largely grouped into three tracks: the provision of opportunities for physical activities, the recovery from 
stress and fatigue, and the facilitation of social contacts and cohesion.

Indeed, Public Space provides residents with the opportunities to have a direct contact with the natural environment, and hence offering them with positive restorative effects on their health and wellbeing, while at the same time providing a buffer against stressful life events (van den Berg et al. 2010). Nutsford, Pearson and Kingham (20II) have argued that the benefits of green space on mental health and wellbeing may also arise from participation in activities occurring in these spaces, such as social interaction or physical, leading to alleviation of stress and anxiety and improved mood and attention (Nutsford, Pearson and Kingham 20I3)

The appreciation of any public space in an urban area is obvious since it is hard to find considering the pressure of rapid urbanization in cities. Where access to open space in the countryside is unlimited, in cities, it becomes particularly important (Maas et al. 2006). This means that the ability of urban residents to access any available 'public space' as well as any attributes leading to both an increase in activities, users and hence frequency is equally significant, especially during a pandemic.

In this perspective, the covid-19 impact on public space remains a catalyst in reexploring the meaning and value of public space. On one hand, restricting people's access to public space is seen to reduce spread, while on the other, people's access to public space, especially parks and green areas, may help in reducing Covid-1 9 related stress (Freeman and Eykelbosh, 2020)

\section{Research Methods}

\section{I. The Research area}

Kigali city is rapidly urbanizing and the spatial expansion of the city has largely been influenced by its hilly topography separated by wetland valleys the hilltops. Whereas the formal/planned neighbourhood tend to occupy the habitable hilltops and slops, the informal/unplanned neighbourhoods tend to occupy the lower slopes close to wetland valleys(Baffoe et al. 2020). Since the 2013 Kigali city Masterplan and environmental policies (REMA, 2017) do not permit settlements at slopes above $35 \%$ and/or inside wetland valleys, most human settlements are found on the gentle slopes (Uwimbabazi and Lawrence, 20I I).

The research area is in Kicukiro district, one of the three districts composing Kigali city. The case study area is part of the KK $33 \mathrm{Av}$, an avenue located in between two neighbourhoods; Kimisange and Kigarama as illustrated in Figure 2. Kimisange neighbourhood is composed of three upper middle income housing estates constructed after 2010. They include; Mountain View, Kyberion and Comfort homes, whereas Kigarama neighbourhood is a mixed-income neighbourhood constructed before 2000. The two neighbourhoods host approximately 200 households and there is no formal public space in existence. The construction of a cultural village by the Rwanda Development Board (RDB) is underway at the top of mount Rebero, about two kilometres South East of the study area. The entire neighbourhood has been mapped as the future for middle and high income residents in Kigali city (Baffoe et al. 2020). The area is characterized by pretty new streets, tarmacked in 2019 and attractive walkways laced with flower gardens. Efforts put in by government in partnership with residents to light the streets further help improve the image and safety of the neighbourhood.

The juxtaposition of the two neighbourhoods and the research area offers them prime 
opportunity as users of the space, be it active or passive recreation. Before Covid-19, residents could organize group sports inside school playgrounds, community Centres, or undeveloped plots, especially during the weekends. Areas such as GS Kimisange school, association mwana ukundwa community centre and undeveloped plot on KK 776 street would gather groups of about 60 people on Saturdays after umuganda or Sunday mornings.

The forest reserve adjacent to the study area is also increasingly used for recreational activities, specifically because its natural and steep slope (approximately 45 degrees) is good for cardio exercises.

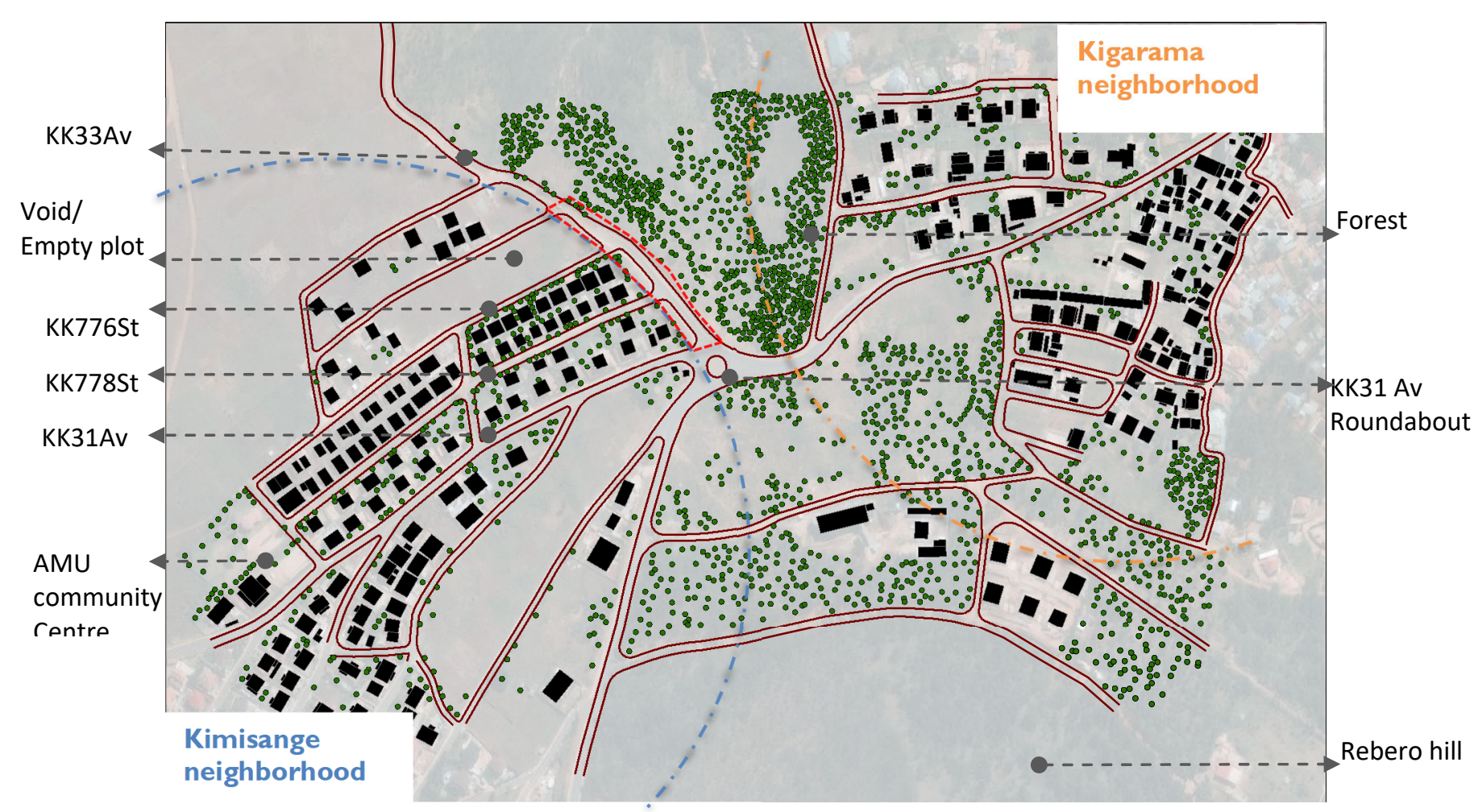

Figure 2. Research area. Source: Google earth modified by Author

The area, due to its location on the slopes of mount Rebero, is also popular for views and $180^{\circ}$ vista of Kigali city and perhaps the best view point for Mount Kigali, being the tallest mountain in Kigali at about 1,800 meters above sea level, as illustrated in Figure $3 c$, which is also a source of fresh breeze to this area. In between the two neighbourhoods is a forest reserve adjacent to the KK33Av, giving it a serene environment. The low traffic volume and steep sloped streets make them attractive for sporting activities as illustrated in Figure $3 \mathrm{a}, \mathrm{b}$. In line with this, the recent use of the KK3I Av roundabout as the end point of 'Tour du Rwanda' international cycling competition event in February 2020 placed the site on the national and global scene, and introduced a new attraction to the event attendees. People travel from other neighbourhoods in Kigali and park their cars in either of the three estates' streets to take the thrill of climbing down and up the streets and the forest. 

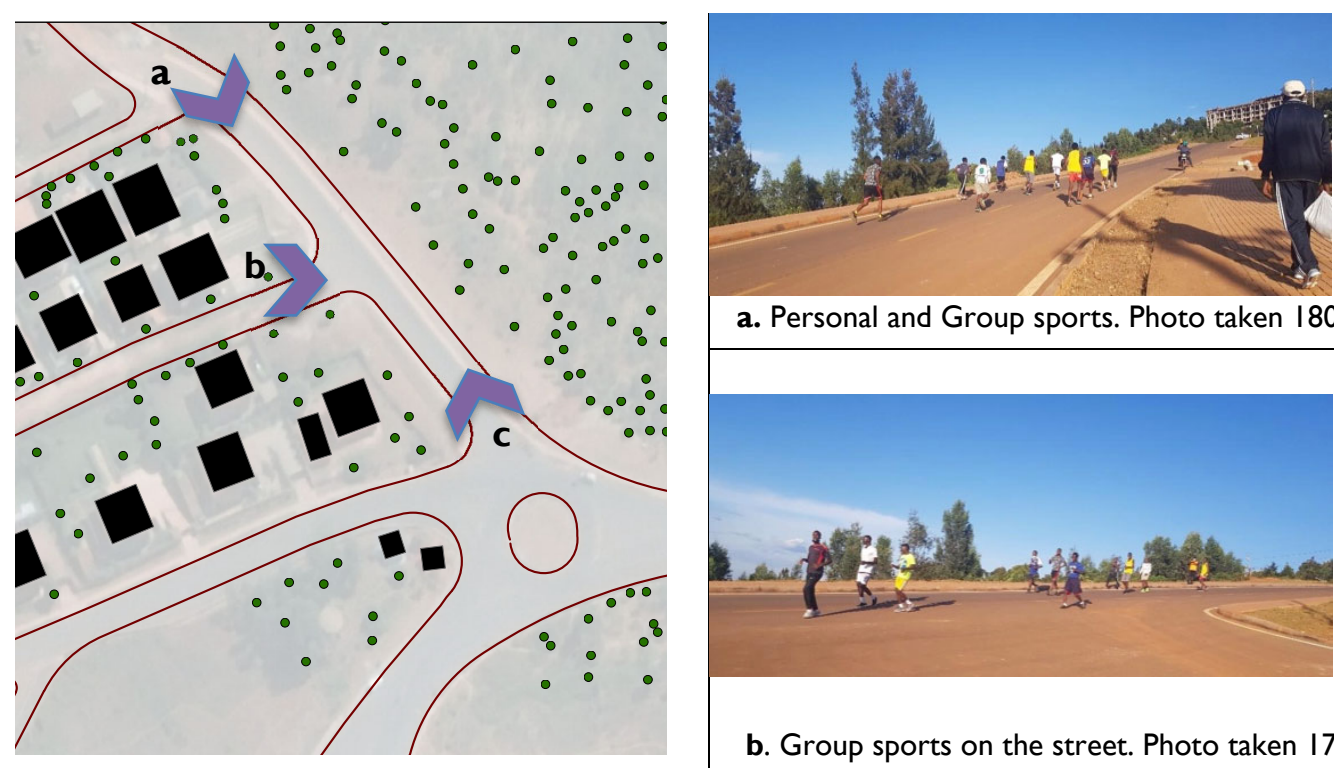

a. Personal and Group sports. Photo taken I800h

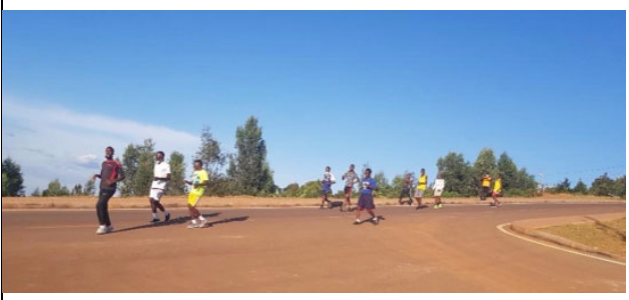

b. Group sports on the street. Photo taken $1730 \mathrm{~h}$

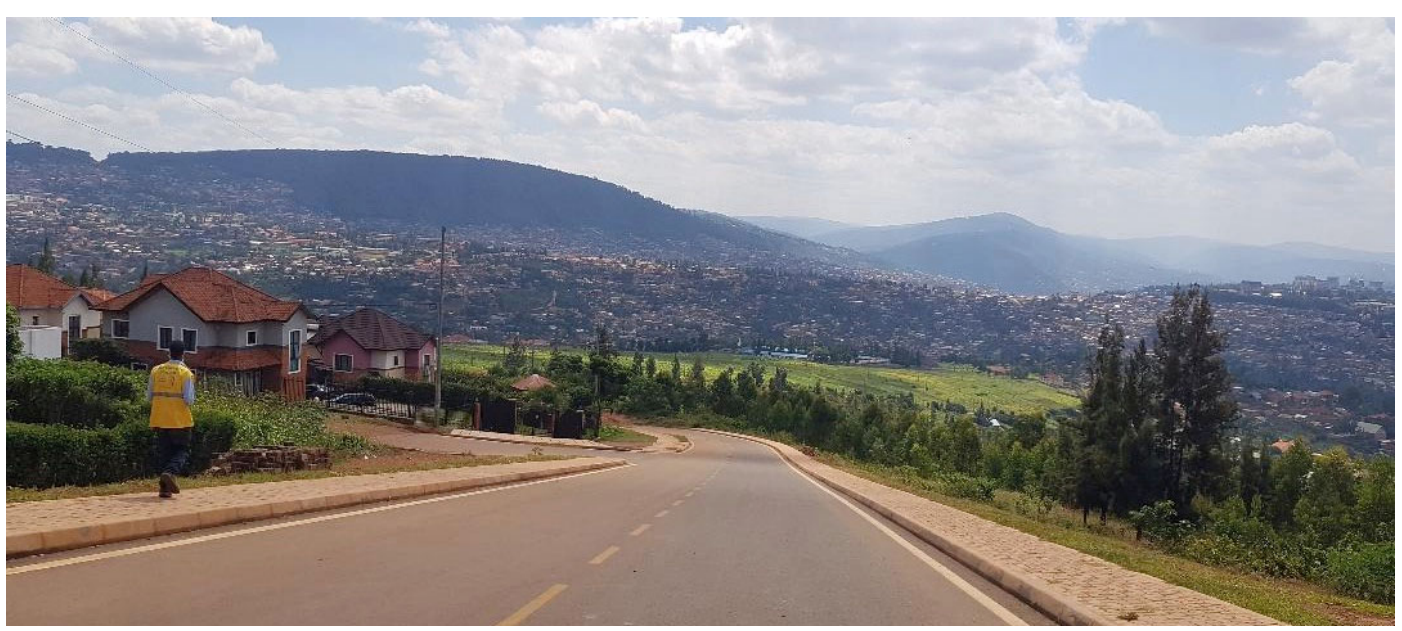

c. Street features, slope, view and vista. Photo taken I200h

Figure 3. A zoom into the study street. Source: Author

\subsection{Data Collection and analysis}

Through field observation, the empirical evidence is extracted from activities that took place before Covid-19 and those that are taking place currently. Patterns of use are explored in four tracks; length of stay, preferred visit time, frequency of recent use and type of activities. Mapping is done by marking individuals' activity points, considering their types, number of users, users' age and how they use the space related to the physical features of the street. Activity mapping and analysis reveals the nature and frequency of activities as well as the most and least sub-areas used. It is therefore possible to relate the empirical evidence to theoretical underpinnings in order to arrive at a critical discussion about how public space and quality of life interrelate. 


\section{Results and Discussion}

4.I. Understanding the changing quality of public life in Kimisange

The results in Table I present the case street as a significant hotspot for recreational activities during the Covid- 19 period during both weekdays (a, b) and weekends (c, d). Although linear in configuration and relatively small in size, the area does qualify to be public space since it is characterized by consistent social interaction between people and can be freely and easily accessed by everyone regardless of age, gender and income. This is a first important criterion for a public space to be capable of taking care of the public needs of all its users.

Table I. Activity mapping before and during Covid-19. Source: Author

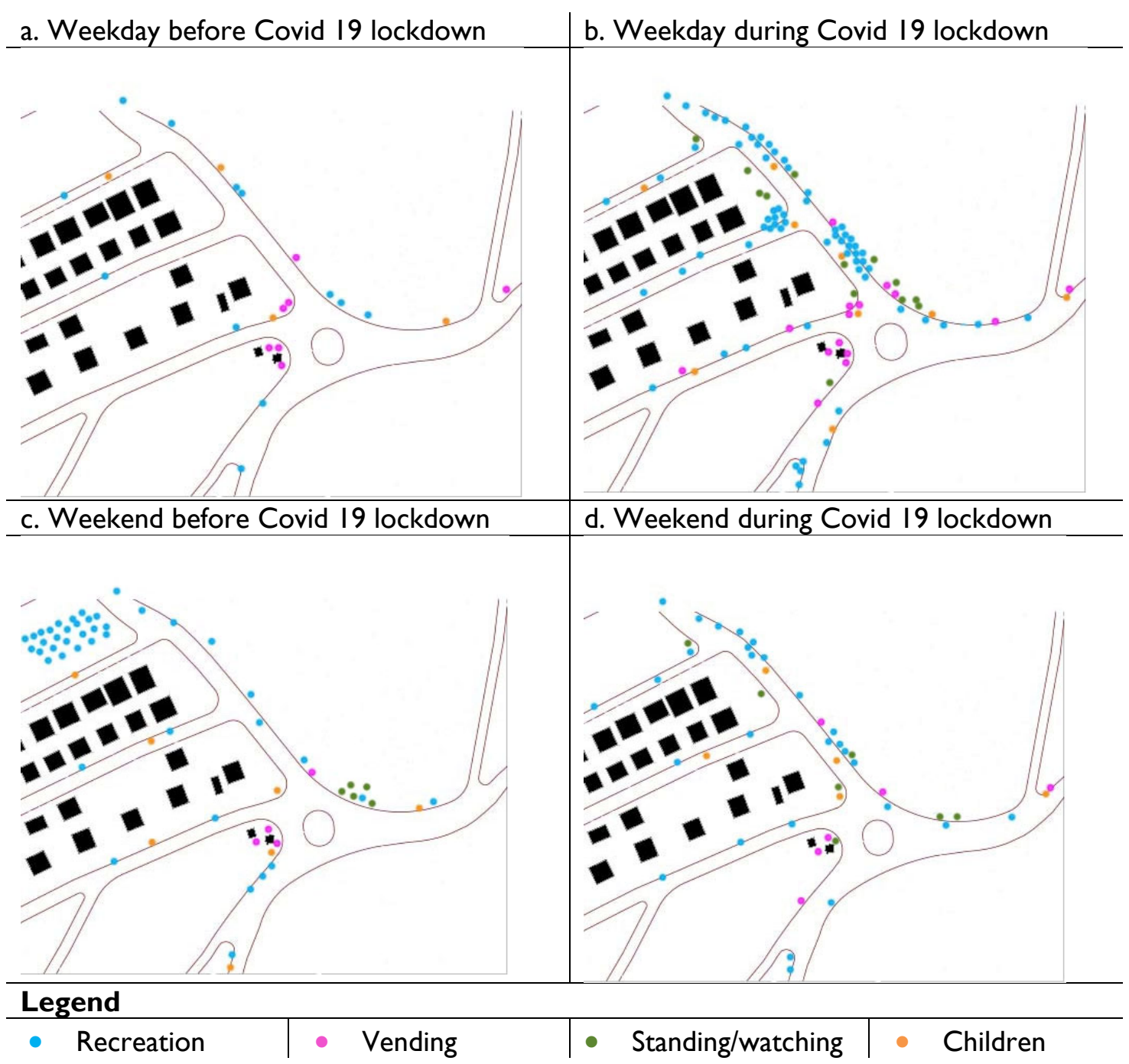

The patterns of use during weekdays and weekends are significantly varied during and before the pandemic. Most people preferred to use the street more freely, and not limiting their activities to sidewalks on the urban void otherwise used for group sports in the weekends before the lockdown.

The absence of one huge group doing sports at the urban void, shows adherence to 
government's recommendations to keep social distancing, and users seem to innovatively use the available space for their recreation while at the same time respecting the health protocol in place. Less people used the street in weekends than weekdays, unlike before lockdown. This change of frequency in itself highlights a changing pattern of use of urban space; whereby before lockdown, weekdays would be dedicated to work or errands outside home but during a lockdown, people are more available at home/within neighbourhoods while at the same time with the need to do recreational activities outside the home at every available opportunity.

Results in Table 2 indicate that more people used the street for recreational activities, be it personal or group activities, during the pandemic than before. More mixed groups, of different ages used the street during than before the pandemic, hence the higher effective area used. These findings may seem to relate/contradict the government's recommendation that residents minimize trips outside home and avoid group sports, informed by health research findings that travels outside home and behaviours in public space may lead to a potential risk of infection.

Table 2. Analysis of human, urban space and behaviour on the street before and during the pandemic. Source: Author

\begin{tabular}{|c|c|c|c|c|c|c|}
\hline & $\begin{array}{l}\text { Personal } \\
\text { activities }\end{array}$ & $\begin{array}{l}\text { Group } \\
\text { activities }\end{array}$ & $\begin{array}{l}\text { Different } \\
\text { ages }\end{array}$ & Mixed use & $\begin{array}{l}\text { Effective } \\
\text { area used }\end{array}$ & $\begin{array}{l}\text { Street } \\
\text { features }\end{array}$ \\
\hline \multicolumn{7}{|c|}{ Before Covid-19 } \\
\hline \multicolumn{7}{|c|}{ During Covid-19 } \\
\hline Legend & Lon & & & & & igh \\
\hline
\end{tabular}

The results show that there is still significant evidence of the wide set of benefits derived from public space. This leaves no chance to undervalue any public space in our cities, including those at the neighbourhood scale. Comparing the street before and during Covid-19, there are more group recreational activities, as the street is able to absorb activities that used to happen in gymnasiums and playgrounds that remain closed. The vibrant street further attracts children who either watch or join in the sporting activities, and more vendors of telecommunication services. Before Covid-19, more people from outside the neighbourhood would come to enjoy the vista, but during Covid-19, more people from outside come to do sports in groups. Whereas activities (mainly walking) used to happen mainly only along the sidewalks, the effective area of the street used has grown threefold as active and passive activities are happening right inside the street; and requirements for distancing mean the sidewalk is inadequate. Unlike before, the proportions between use of space during weekday and weekends 
have shifted significantly. Clearly, even with no improvement on its physical features in the past five months, outdoor space has become more desirable, as people need a break from staying indoors and at home to catch more fresh air.

At a time when the pandemic is taking a toll on public life, it is interesting to see the way users are innovating outdoor space and transforming an area initially provided for vehicular traffic into a recreational area for pedestrian activity. The natural 'gym' requires no equipment and all are welcome.

Therefore, to sustain high quality of life benefits from public space, it is important to emphasize on 'sociability' qualities that can help promote vibrant public life in neighbourhood streets as public space. Recreational activities happening on the street, coupled by the fact that group sports dominate the area, improve sociability of the street immensely. This interaction attracts many more people from the neighbourhood and beyond, and the growing presence of children in the street justify just how fascinating the space has become.

With caution on matters of health and safety, it is also true that popular and group activities such as sports are likely to make physical distancing rules hard to follow especially when excitement and senses are at the peak. There has also been concern on the increased footprint for recreation, now covering $70 \%$ of the street and feared risks of road accidents especially with drivers not so familiar with the pop-up use of space. Nonetheless, it is conversations like this that drive the search for a paradigm shift in post-Covid planning, and are likely to form a firm base for tactical urbanism through which we can ensure that the future is well informed by the current empirical evidence, especially the perception and use of neighbourhood streets as public space.

\subsection{Resisting normalization of social distancing}

Most Covid- 19 related restrictions are obviously too many because there is evidence on how badly the pandemic has hit other regions and there had not been any news of vaccines or confirmed cure for the same when the study was conducted in 2020 . The Covid-19 period is therefore, assumedly a time to unlearn the social life and public space as we used to know it, and learn new ways of work and study. Populations are quickly adopting to new norms such as e-learning and virtual meetings, which are making the digital space more prominent than ever in people's lives, but does it dilute the human desire for social cohesion? There is need to guard against a common tendency for temporary measures to become more permanent.

This study has confirmed that when time and conditions allow neighbourhood residents to interact with newcomers to the street, the relationship grows gradually and increasingly residents get recruited to some of the group sporting activities. More and more residents are now actively involved in sports, both from within the neighbourhood and visitors. Even though the study area is not designed for sports, it remains attractive for sports and the people's positive perception goes a long way to improving the social utility of the area, which may render the environmental comfort to be not so strong a criterion for a successful public space as theory had depicted (Gehl, 20II).

\section{Conclusion}

To sum up, the early findings from the observation of activities in the case study street 
confirm that the increasing presence of people in the street for recreational activities has and continues to influence conceptualization of the street as public space. Rather than see public space as something permanently fixed to a particular locality and inked into a static city map, the study has instead introduced a new sense that public space actually moves and evolves as shaped by peoples' activities

Therefore, it becomes increasingly acceptable that public space, is to be seen as places where people willingly visit, do activities they enjoy, and spend more time with each other. In this perspective, if we were to unpack what it takes to catalyse a high quality of life in cities and neighbourhoods, then the answer might not be far from the form of our streets.

Considering the Covid-19 impact on public life and the increased need for outdoor activities, the study has showed that sociability in public space has every potential to rebrand neighbourhood streets into successful public spaces. Indeed, public life is based on people's need of being with others and this social need gets even more valuable in difficult times. Regardless of the physical features remaining the same, the daily and repetitive patterns of use during the lockdown enhance both necessary activities and social activities, improving quality of life on the street even though the pandemic was feared to negatively impact on people's appreciation of any public space outside home. This way, features like steep topography, that would otherwise be seen as impediments of social activities, become an opportunity by enhancing both the active recreational activities as well as passive activities of standing and watching.

Whereas the street is traditionally known as a conduit of movement from point $A$ to $B$, the current use seems to have transformed its meaning to a fascinating part of the neighbourhood's social life. The street is no longer just for cars but also for people, no longer just for adults but also for children and recreation is no longer just a weekend activity, but also for weekdays and enjoyed in the presence of other people. This further reinforces the notion of street as public space.

More importantly, it could be argued that this contextual manifestation, especially in times when the pandemic preys on public life globally, offers hope that when the crisis comes to an end, public spaces could bounce back stronger as a catalyst for public life and public health. Although over the last 12 months, people have had to adopt to new social behaviour, keeping social distances and staying home, the emotional connections to other people and public space seem not to have been lost. As we look forward to the lessons Covid-19 will have taught us with respect to perceiving, using and designing cities and neighbourhoods, possibilities to move our mindsets in new directions and rethink the intersection between pandemic and urban life favourably. Public space has to remain central in the Covid-19 debate and beyond, given the diversity of innovations around its use, which further informs future planning and design.

\section{References}

Appleyard, B., Cox, L. (2006). At Home in The Zone: Creating livable streets in the U.S., Planning. Vol. 72, no. 9, pp. 30-35.

Baffoe, G., Malonza, J., Manirakiza,V., Mugabe, L. (2020). 'Understanding the Concept of Neighbourhood in Kigali City, Rwanda', Sustainability 12(4). 10.3390/su I 204 I 555 
Bhowmick, S. (2019, May 17). Toward the SDGs: The Rwanda story. Observer Research Foundation. Available at https://www.orfonline.org/research/toward-the-sdgs-the-rwandastory-50935 (Accessed: I 5 July 2020)

Björk, J., Albin, M., Grahn, P., Jacobsson, H., Ardö, J., Wadbro, J., Östergren, P-O. and Skärbäck, E. (2008). Recreational values of the natural environment in relation to neighbourhood satisfaction, physical activity, obesity and wellbeing. Journal of Epidemiology and Community Health, 62(4), e2.

Bravo, L. (2013). Open Spaces, Public Spaces, Publics, Open-minded Places. Ricerche e progetti per il territorio, la città e l'architettura. Special Issue No I/20I3

Bravo, L., Guaralda, M. (2016). 'An open access forum for the discussion and advancement of research about public space', The Journal of Public Space, I(I), pl-4.

Caldwell, G. A., \& Guaralda, M. (2016). Blurring the physical boundaries of the city: Media architecture and urban informatics for community engagement. In G. A. Caldwell, C. H. Smith, E. M. Clift \& G. Cairns (Eds.), Digital Futures and the City of Today New Technologies and Physical Spaces (pp. 235-250). Bristol, UK: Intellect.

Carmona, M., Heath, T., Oc, T., \& Tiesdell, S. (2010). Public Places Urban Spaces: The Dimensions of Urban Design. New York: Taylor \& Francis Ltd.

Carmona, M. (2019). 'Principles for public space design, planning to do better', Urban Design International, 24(I), p47-59.

Corbera, E., Anguelovski, I., Honey-Rosés, J., Ruiz-Mallén, I. (2020). 'Academia in the time of COVID-1 9: Developing an ethics of care', Planning Theory \& Practice, I-9. doi: I0.1080/| 4649357.2020 .175789 |

Das, D. (2008). Urban Quality of Life: A Case Study of Guwahati, Springer Science+Business Media B.V., Social Indicators Research, 88, pp. 297-310.

Freeman, S., Eykelbosh, A. (2020). COVID-I 9 and outdoor safety: Considerations for use of outdoor recreational spaces. National Collaborating Centre Environmental Health. 2020.

Available online: https://www.researchgate.net/publication/34072I289 COVID-

19 and outdoor safety Considerations for use of outdoor recreational spaces Prep ared by/link/5e9a24a8299bf /3079a24c5c/download (Accessed: 16 July 2020)

Garau, P., L. Lancerin, and M. Sepe. (20I5). The Charter of Public Space. Trento: LiST

Gehl, J. (2010). Cities for People. Washington DC: Island Press

Gehl, J. (20II). "Life Between Buildings: Using Public Space" Translate by Jo Koch. Library of Congress Cataloguing in Publication Data. Washington, DC: Island Press.

Government of Rwanda. (2020). Office of the Prime Minister official twitter handle. Available at https://twitter.com/PrimatureRwanda/status (Accessed: 2 July 2020)

Government of Rwanda. (2012). Rwanda Vision 2020 revised 2012. Available at http://www.minecofin.gov.rw/fileadmin/templates/documents/NDPR/Vision_2020.pdf (Accessed: 12 July 2020)

Government of Rwanda. (20I5). National Urbanisation Policy. Available at https://www.bpmis.gov.rw/asset_uplds/files/National\%20Urbanization\%20Policy.pdf (Accessed 20 June 2020)

Government of Rwanda. (2019a). 2019 Rwanda Voluntary National Review (VNR) Report. Available at https://sustainabledevelopment.un.org/content/documents/23432Rwanda_VNR_Documen $\mathrm{t}$ _Final.pdf (Accessed: 25 May 2020)

Gubic, I. and Baloi, O. (2020). 'Public open space initiatives for healthier cities in Rwanda', Journal of Public Space, 5(2), pp. I29-I 46.

Joye, Y., Willems, K., Brengman, M. and Wolf, K. (20I0). 'The effects of urban retail greenery on consumer experience: Reviewing the evidence from a restorative perspective', Urban Forestry \& Urban Greening, 9(I), pp. 57-64. 
Kondo, M. C., Fluehr, J., M., McKeon, T. \& Branas, C. C. (2018). 'Urban green space and its impact on human health', International journal of environmental research and public health, I5(3), p. 445

Lee, A. and Maheswaran, R. (20II). 'The health benefits of urban green spaces: a review of the evidence', Journal of Public Health. 20I I;33(2), P2 I 2-222

Maas, J., Verheij, R., Groenewegen, P., (2006). 'Green space, urbanity, and health: how strong is the relation?', Journal of Epidemiol Community Health, 60(7), P587-592

Malonza, J. and Rukwaro, R. (2017). 'Rethinking urban public space in the rapidly urbanizing East African region; case of car free zone, Kigali', Africa Habitat Review. ISSN25 I 9-785 I, I I ( I), pII07-II 24.

Malonza, J., Rukwaro, R., Anyamba, T. (2018). 'Mapping socio-cultural influences in contemporary urban public open space: The case of Biryogo, Kigali city', International Journal of Creative Research and Studies ISSN-0249-4655, 2(9), p59-77

Mehta, V. (20I4). 'Evaluating public space', Journal of Urban design, I9(I), p53-88.

Nutsford, D., Pearson, A., Kingham, S. (2013). 'An ecological study investigating the association between access to urban green space and mental health', Public Health. 2013;127(II), pl005-I0II.

Project for Public Spaces (2017a). Street as places- Using streets to rebuild communities. Available at: https://www.pps.org/product/streets-as-places- using-streets-to-rebuild communities (Accessed I 2 July 2020).

Project for Public Spaces (2017b). Qualities of a Great Street. Available at: https://www.pps.org/reference/qualitiesofagreatstreet (Accessed I 9 July 2020)

REMA. (2017). State of Environment and Outlook Report: Achieving Sustainable Urbanisation.

Sandford, A. (2020). Coronavirus: Half of humanity now on lockdown as 90 countries call for confinement. Available at: https://www.euronews.com/2020/04/02/coronavirus-in-europespain-s-death-toll-hits-10-000-after-record-950-new-deaths-in-24-hou (Accessed: 16 July 2020).

Silva, M. M. and Costa, J. P. (2018). 'Urban floods and climate change adaptation: The potential of public space design when accommodating natural processes', Water, I0(2), pl 80.

Thompson, I. (2004). Ecology, community and delight: Sources of values in landscape architecture. London: Taylor \& Francis.

UN-Habitat (2020) UN-Habitat Guidance on COVID-I 9 and Public Space. UNHabitat, Nairobi.

UN-Habitat and World Health Organization. (2020). Integrating health in urban and territorial planning: a sourcebook. World Health Organization.

UN-Habitat. (2015). Global public space toolkit: From global principles to local policies and practice.

UN-Habitat, Nairobi. ISBN: 978-92-I-I32656-7.

UN-Habitat (2013) Streets as Public Spaces and Drivers of Urban Sustainability. UNHabitat, Nairobi

Uwimbabazi, P. and Lawrence, R. (20II). 'Compelling Factors of Urbanization and Rural-Urban Migration in Rwanda', Rwanda Journal, Series B, 22(I), p9-26.van den Berg, A., van Winsum-Westra, M., de Vries, S. and van Dillen, S. (2010). 'Allotment gardening and health: a comparative survey among allotment gardeners and their neighbors without an allotment', Environmental Health, 9(74).

van den Berg. A., Maas, J., Verheij, R. and Groenewegen, P. (2010). 'Green space as a buffer between stressful life events and health', Social Science \& Medicine. 2010;70(8), pl2031210.

WHO, (2020a). Coronavirus disease (COVID-19) advice for the public.

Available at https://www.who.int/emergencies/diseases/novel-coronavirus-2019/advice-forpublic (Accessed 19 May 2020).

WHO, (2020b). Rwanda hastens safety measures against novel coronavirus. Available at https://www.afro.who.int/news/rwanda-hastens-safety-measures-against-novel-coronavirus (Accessed 5 May 2020). 